\title{
INISIASI PEMBENTUKAN DEMONSTRASI PLOT AREA KAMPUNG KELOR UNTUK PENCEGAHAN STUNTING
}

\author{
Nur Chabibah $^{1^{*}}$, Milatun Khanifah ${ }^{2}$, Rini Kristiyanti ${ }^{3}$ \\ 1,2,3 Jurusan Diploma III Kebidanan/Fakultas Kesehatan, Universitas Muhammadiyah Pekajangan Pekalongan \\ *Email: nchabibah@ymail.com
}

\begin{abstract}
Abstrak
Status gizi buruk pada balita dapat menimbulkan pengaruh yang sangat menghambat pertumbuhan fisik, mental maupun kemampuan berpikir yang pada akhirnya akan menurunkan produktivitas kerja. Penelitian sebelumnya menunjukkan bahwa pohon Kelor (Moringa oleifera) telah meningkatkan status gizi anak dengan Protein Energy Malnutrition (PEM). Keinginan masyarakat dalam mewujudkan masyarakat bebas stunting perlu didukung dengan peran aktif institusi. Tujuan kegiatan ini adalah menfasilitasi masyarakat dalam pembentukan kampung kelor. Pembentukan kampung kelor ini diharapkan meningkatkan asupan gizi balita. Metode yang dilakukan antara lain sosialisasi hasil penelitian manfaat dan nilai gizi tanaman kelor, pendekatan mitra lintas sektor dalam perumusan kerjasama pembentukan kampung kelor, analisa lokasi, tahap pembenihan, tahap penanaman, tahap pemeliharaan, tahap monitoring dan evaluasi pelaksanaan kegiatan dan pembuatan rencana tindak lanjut untuk pelatihan pembuatan produk pasca panen. Luaran pengabdian masyarakat berupa peningkatan pengetahuan tentang nilai gizi dan manfaat tanaman kelor, adanya kerjasama lintas sector dalam pembentukan dan pemeliharaan kampung kelor, terbentuknya kampung kelor dan peningkatan keterampilan kader dalam memanfaatkan dan mengolah hasil panen tanaman kelor.
\end{abstract}

Kata Kunci : Kampung Kelor, Stunting

\section{Abstract}

Stunting can cause an influence that greatly inhibits physical, mental and thinking growth which will ultimately reduce work productivity. Previous research has shown that "Kelor" tree (Moringa oleifera) has improved the nutritional status of children with Protein Energy Malnutrition (PEM). The desire of the community to create a stunting free society needs to be supported by the active role of the institution. The purpose of this activity is to facilitate the community in the formation of kelor villages. The formation of the kelor village is expected to increase the nutritional intake of toddlers. The methods include socializing the results of research on the benefits and nutritional value of Moringa plants, approaching cross-sector partners in the formulation of cooperation in establishing kelor villages, analyzing locations, seeding stages, planting stages, maintenance stages, monitoring and evaluating activities and making follow-up plans for training in making post-harvest products. The 
level of community service in the form of increasing knowledge about the nutritional value and benefits of Moringa plants, the existence of cross-sector cooperation in the formation and maintenance of kelor villages, the establishment of kelor villages and increasing community skills in utilizing and processing Moringa crop yields.

Keywords: Kelor Village, Stunting

\section{PENDAHULUAN}

Kekurangan energi dan protein (KEP) banyak dijumpai pada anak-anak, dimana konsumsi protein dan energi belum memadai untuk memenuhi kebutuhan nutrisi tubuh. Sementara kekurangan protein dapat terjadi karena diet seseorang cukup memenuhi kebutuhan energi tetapi tidak memiliki protein, dalam banyak kasus kekurangan akan ganda. KEP juga dapat terjadi pada orang-orang yang tidak mampu menyerap nutrisi penting atau mengkonversikannya ke energi penting untuk pembentukan jaringan sehat dan fungsi organ. Malnutrisi adalah faktor utama dalam menyebabkan kematian bayi di daerah tropis dan sub-tropis (Srikanth et.al, 2014)

Badan kesehatan dunia (WHO) memperkirakan bahwa 54 persen kematian anak disebabkan oleh keadaan gizi yang buruk. Sementara masalah gizi di Indonesia mengakibatkan lebih dari 80 persen kematian anak (WHO, 2011). Hasil Riset Kesehatan Dasar (Riskesdas) tahun 2013 secara Nasional diperkirakan Prevalensi Balita Gizi Buruk dan Kurang sebesar 19,6 \%. Jumlah ini jika dibandingkan dengan hasil Riskesdas tahun 2007, terjadi peningkatan yaitu dari $18,4 \%$. Bila dilakukan konversi ke dalam jumlah absolutnya, maka ketika jumlah Balita tahun 2013 adalah 23.708.844, sehingga jumlah Balita gizi buruk dan gizi kurang sebesar 4.646.933 Balita (Kompasia, 2014)

Status gizi buruk pada balita dapat menimbulkan pengaruh yang sangat menghambat pertumbuhan fisik, mental maupun kemampuan berpikir yang pada akhirnya akan menurunkan produktivitas kerja. Balita hidup penderita gizi buruk dapat mengalami penurunan kecerdasan (IQ) hingga 10 persen. Keadaan ini memberikan petunjuk bahwa pada hakikatnya gizi yang buruk atau kurang akan berdampak pada menurunnyakualitas sumber daya manusia. Selain itu, penyakit rawan yangdapat diderita balita gizi buruk adalah diabetes (kencing manis)dan penyakit jantung koroner. Dampak paling buruk yangditerima adalah kematian pada umur yang sangat dini (Samsul, 2011 dalam Khanifah 2017).

Berbagai upaya telah dilakukan oleh pemerintah, khususnya Dinas Kesehatan, baik pendekatan strategis maupun pendekatan taktis. Pendekatan strategis yaitu berupaya mengoptimalkan operasional pelayanan kesehatan terhadap ibu hamil dan pelayanan kesehatan balita diantaranya pengoptimalan fungsi posyandu. Pendekatan taktis merupakan upaya antisipasi meningkatnya prevalensi balita gizi buruk serta upaya penurunannya melalui berbagai kajian atau penelitian yang berkaitan dengan balita gizi buruk (Kemenkes RI, 2011).

Penelitian yang dilakukan oleh Para ahli telah menunjukkan bahwa pohon paha (Moringa oleifera) telah meningkatkan status gizi anak dengan Protein Energy Malnutrition (PEM). (Arbiet, 2013). Pohon ini tumbuh subur dalam mengembangkan negara termasuk India terutama di daerah pedesaan, di mana prevalensi kekurangan gizi tinggi (Dhakar et.al, 2011)

Nilai gizi tanaman kelor yang sangat tinggi dan telah terbukti dapat meningkatkan status gizi tidak hanya untuk bayi dan balita tetapi juga untuk ibu hamil maupun ibu menyusui. Oleh karena itu, dalam pengabdian tim melakukan inisiasi pendekatan lintas sector dalam perwujudan kampung kelor sebagai fasilitas untuk desa dalam

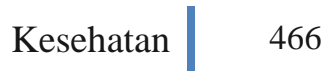


membudidayakan dan memanfaatkan tanaman kelor sebagai bahan makanan untuk peningkatan kesehatan ibu dan balita di desa Tangkil Tengah Kecamatan Kedungwuni Kabupaten Pekalongan.

\section{METODE}

Metode yang digunakan dalam kegiatan kemitraan ini meliputi pendekatan mitra, koordinasi mitra, pembeuatan nota kesepahaman, sosialisasi manfaat tanaman kelor pada kelompok rentan gizi, dan pembuatan demonstrasi plot area lahan penanaman tanaman kelor di desa Tangkil Tengah.

Tim mempersiapkan segala peralatan yang di butuhkan seperti draf nota kesepahaman dalam pendekatan lintas sector adan pembentukan kerjasama, alat dan bahan lain yang digunakan dalam acara sosialisasi manfaat tanaman kelor pada mitra dan kelompok sasaran rentan gizi seperti infokus, lcd dan peralatan alat tulis maupun angket dan pada saat pelaksanaan pembuatan demonstrasi plot area tim mempersiapkan bbenih tanaman kelor bersama dengan UPT pertanian melakukan tahap pembibitan dan alat pertanian yang dipersiapkan untuk melakukan penanaman bibit yang sudah ada di lahan demonstrasi plot are.

\section{HASIL DAN PEMBAHASAN}

\section{Pendekatan mitra}

Pendekatan mitra dilakukan pada beberapa rapat lintas sector baik yang dilakukan di instasi kesehatan, kecamatan Kedungwuni maupun di level Desa. Pendekatan awal yang dilakukan adalah mensosialisasikan hasil hasil penelitian yang telah di lakukan oleh tim dengan pemberian fortifikasi bubuk daun kelor dalam susu kedelai yang data meningkatkan status gizi balita kurag gizi dan pemberian kapsulbubuk daun kelor yang secara signifikan dapat meningkatkan status gizi mikro dan makro ibu nifas yang berpantang makanan. Sehingga mitra mengetahui secara langsung bukti nyata penelitian yang telah dilakukan di area Kecamatan Kedungwuni.

Pendekatan mitra yang kedua dilakukan penawaran kerjasama dalam pengembangan kampung kelor melalui pembuatan demonstrasi plot area kampung kelor yang hasilnya dapat dimanfaatkan oleh warga desa dan pengembangan desa tersebut

Pendekatan tidak hanya dilakukan pada pihak desa dan Kecamatan tetapi juga pada unit pelaksana teknis pertanian Kecamatan Kedungwuni sebagai penyuluh pertanian dan pengembang aspek pertanian dengan maksud agar mitra UPT pertanian dapatmembantu dalam peyuluhan cara budidaya tanaman kelor pada masyarakat.

\section{Penandatanganan Nota kesepahaman}

Penawarak kerjasama pada pendekatan mitra yang bersedia di tindak lanjuti dengan pembuatan draff nota kesepahaman antara STIKES Muhammadiyah dengan Kecamatan Kedungwuni dan UPT Kecamatan Kedungwuni untuk memperjelas aspek kerjasama yang dilakukan dan mengetahuai hak dan kewajiban masing-masing serta menentukan desa mana yang digunakan sebagai demonstrasi plot area dalam penanaman tanaman kelor.

Memorandum of Understanding (MOU) Pembuatan Demonstrasi Plot Area Kampung Kelor disetujui di Desa Tangkil Tengah. Sebagai langkah awal pembudidayaan tanaman kelor.

\section{Sosialisasi Manfaat Tanaman Kelor}

Tahap sosialisasi manfaat tanaman kelor tidak hanya dilaksanakan di Desa yang mempunyai sasaran kelompok rentan gizi seperti balita gizi kurang, Ibu hamil KEK dan ibu nifas yang berpantang makanan. Sosialisasi ini berlangsung di Puskesmas Kedungwuni maupun di Balai Desa. Sosialisasi akan manfaat tanaman kelor ini bertujuan agar masyarakan mengetahuan manfaat tanaman kelor, mau mengkonsumsi tanaman kelor serta tau cara pengolahan tanaman kelor

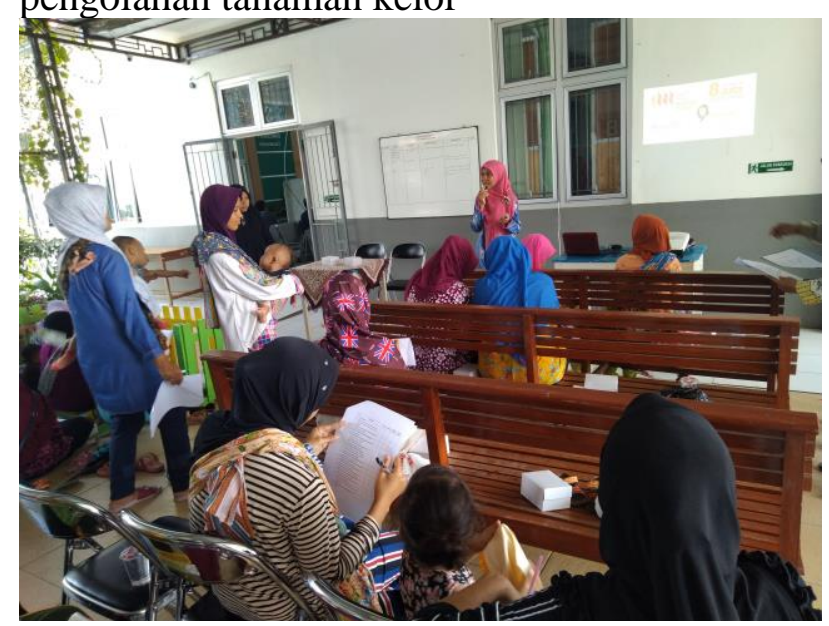

Gambar 1. Sosialisasi Manfaat Tanaman Kelor pada Kelas Balita 
Hasil Sosialisasi masyarakat secara umum menanggapi dengan respon positif terutama pada kelas memasak balita. Ibu-ibu sangan antusias dalam melihat demonstrasi pengolahan daun kelor yang dijadikan makanan balita.

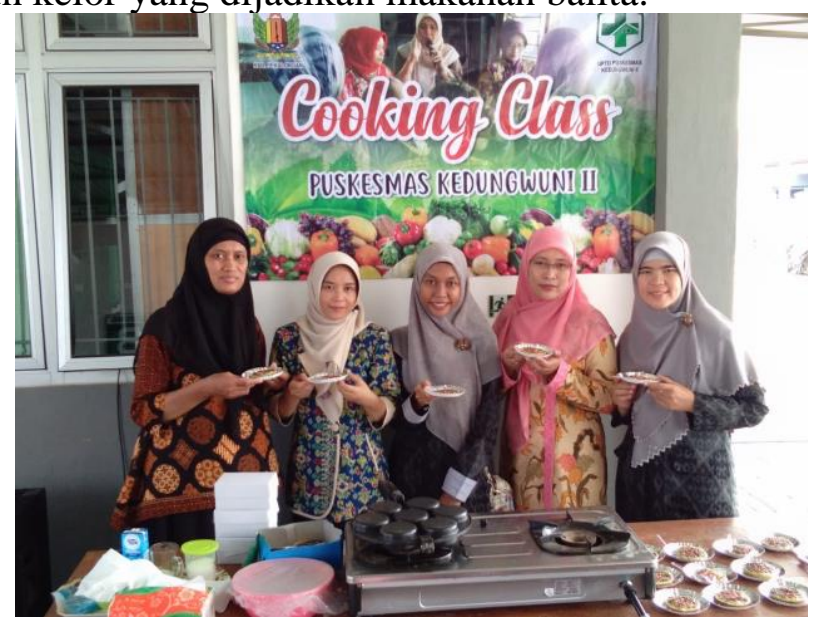

Gambar 2. Kegiatan cooking class sebagai aplikasi manfaat tanaman kelor

Peningkatan pengetahuan masyarakat di harapkan dapat menjadi bekalmasyarakat dalam memperbaiki status gizi anggota keluarganya. Pengetahuan orang tua terutama ibu menjadi faktor yang penting dalam perbaikan gizi anak balita sehingga dapat menunjang perbaikan gizi anak balita mereka. Peningkatan pengetahuan memang tidak selalu menyebabkan perubahan perilaku, perubahan perilaku ditetukan oleh tiga faktor yaitu faktor pemungkin (enabling factor), faktor penguat (reinforcing factor) dan faktor predisposisi (predisposing factor). Pengetahuan adalah salah satu faktor yang mungkin dapat di rubah secara langsung terhadap respon terhadap kesadaran dan pengetahuan. Oleh karena itu, pengetahuan dan sikap ibu balita yang baik pasti akan menunjang perilaku ibu dalam pemberian makanan ke anak balitanya sehingga dapat memaksimalkan peran ibu dalam pemberian makanan tambahan dan pemberian makanan rumah tanggga yang sesuai dengan kebutuhan anak balita (Kusumaningtyas, 2011).

\section{Pembibitan Tanaman Kelor}

Pembibitan tanaman kelor dilakukan oleh UPT pertanian dimana benih telah disediakan oleh tim.
Pembibitan dilakukan secara bertahap dilakukan untuk mengobservasi perkembangan dari tanaman kelor dan penerimaan bibit kelor dari UPT ke Desa dan aplikatif ke lahan demonstrasi plot area Desa Tangkil tengah. Budidaya tanaman kelor yang dilakukan adalah varietas NTT dengan pertimbangan kualitas Calsium dan Ferosus dibandingkan dengan varietas lainnya. Benih ini dikembankan dengan metode generative dengan biji. Periode pembibitan dilakukan pada akhir musim kemarau, sehingga diestimasikan siap tanam di awal musim penghujan.

\section{Penanaman Tanaman Kelor padaLahan Demonstrasi Plot Area Kampung Kelor}

Penanaman bibit Kelor dilakukan secara bertahap oleh tim, UPT pertanian, dan warga Desa Tangkil tengah dimaksudkan untuk mempermudah perawatan dan melihat kesiapanlahan demonstrasi plot area yang telah disediakan di Desa Tangkil tengah. Tahap Pertama telah dilaknakan pada Tahun 2018, dilanjutkan pada awal tahun 2019.

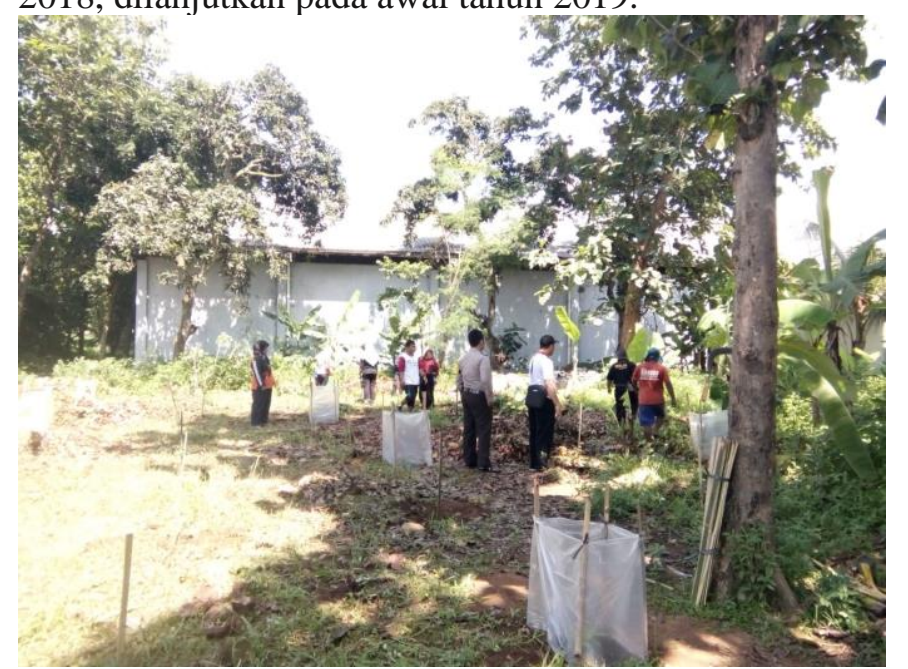

Gambar 3. Lahan Demonstrasi Plot Area Tanaman Kelor Pasca Penanaman

Evaluasi dari kegiatan penanaman yang telah dilakukan masih banyak hambatanterutama dalam perawatan pasca tanam tanaman kelor dan sistem pengairan yang masih manual sehingga masih diperluakan penerapan ipteks dan pendanaan untuk aplikasi dari penerapan ipteks tersebut. 


\section{Evaluasi Kegiatan}

Evaluasi proses pelaksanaan PKM dilakukan bersama dengan UPT Pertanian dan pamong Desa untuk mengidentifikasi kendala yang telah berlangsung dalam pengembangan tanaman kelor di demonstrasi plot area yakni kendala perawatan terutama pengairan yang belum dilaksanakan secara intensive oleh warga. Tindak Lanjut pelaksanaan pengabdian ini adalah dilakukan program kemitraan dengan salah satu kelompok tani di Desa Tangkil tengah dalam menfasilitasi perawatan dan proses selanjutnya budidaya tanaman kelor.

\section{KESIMPULAN}

Rangkaian kegiatan program pengabian kepada masyarakat meliputi pendekatan mitra Kecamatan Kedngwuni, unit pelaksana teknis Kecamatan Kedungwuni, penandatanganan nota kesepahaman demonstrasi plot area kampung kelor, sosialisasi manfaat tanaman kelor pada kelompok rentan gizi, Tahap pembibitan tanaman kelor dan tahap penanaman tanaman kelor di demonstrasi plot area kampung kelor. Seluruh komponen Kecamatan Kedungwuni, UPT pertanian Kedungwuni dan Desa Tangkil tengah mendukung pelaksanaan kegiatan meskipun masih terdapat kendala dalam perawatan tanaman kelor.

\section{UCAPAN TERIMAKASIH (Bila ada)}

Lembaga Penelitian dan Pengabdian Masyarakat Universitas Muhammadiyah Pekajangan Pekalongan dan Desa Tangkil Tengah, Kecamatan Kedungwuni, UPT Pertanian Kedungwuni yang telah menfasilitasi proses kegiatan pengabdian ini sampai akhir.

\section{REFERENSI}

Arbeit, B. \& Kouevi, K.K., 2013. A study on Moringa oleifera leaves as a supplement to West African weaning foods

Dhakar, R. et al., 2011. Moringa: The herbal gold to combat malnutrition. Chronicles of
Young Scientists, 2(3), p.119. Available at: http://www.cysonline.org/text.asp?201 1/2/3/119/90887 [Accessed February 22, 2016].

Kemenkes RI, 2011. Buku-Saku-Antropometri. Jakarta: kemenkes RI

Khanifah, M., Chabibah, N., \& Setyaningsih, P. (2017). Analisa Proximat dan Uji Coba Rasa Produk Fortifikasi Bubuk Daun Kelor (Moringa Oleifera) dalam Susu Kedelai. URECOL, 365-370.

Kompasia. 2012. Balita Gizi Kurang diakses melaluai: http://www.kompasiana.com/debe/4-6-juta-balita-gizi-buruk-kurang-diindonesia-pertanda-ketahanan-panganlampukuningkah_54f4bf79745513982b6c8ec

Kusumaningtyas, D. A. (2011). Pengaruh Penyuluhan Gizi Terhadap Tingkat Pengetahuan Ibu Mengenai Pemberian Makanan Tambahan yang Baik untuk Balita (Doctoral dissertation, UNIVERSITAS SEBELAS MARET).

Srikanth, V.S., Mangala, S. \& Subrahmanyam, G., Improvement of Protein Energy Malnutrition by Nutritional Intervention with Moringa Oleifera among Anganwadi Children in Rural Area in Bangalore, India., pp.32-35. 